\title{
Evaluation of the Mechanical Behavior of Biomorphic Silicon Carbide Derived From Low-Density Peruvian Woods
}

\author{
V.C. Bringas-Rodríguez ${ }^{1}$, J.F. Gamarra-Delgado', M.L. Benavides-Salinas, C.K. Palomino-Naupa, D.L. \\ Mayta-Ponce $^{1}$, G.P. Rodríguez-Guillén ${ }^{1}$ and F.A. Huamán-Mamani1 \\ ${ }^{1}$ Grupo de Investigación en Ciencia y Tecnología de Materiales, Departamento de Ciencias Naturales, Universidad \\ Católica San Pablo, Arequipa, Perú \\ Urb. Campiña Paisajista, Quinta Vivanco s/n, Arequipa 04001, Perú \\ veronicawnh@gmail.com; frank.gamarra23@gmail.com; mirandabenavides7@gmail.com; cpalominon@unsa.edu.pe; \\ dlmayta@ucsp.edu.pe; gprodriguez@ucsp.edu.pe; fhuaman@ucsp.edu.pe
}

\begin{abstract}
Low-density Peruvian woods (tornillo and bolaina) were used as raw material for the manufacture of biomorphic silicon carbide. The plant precursors were physically-mechanically characterized and then pyrolyzed at $900{ }^{\circ} \mathrm{C}$ in an argon atmosphere to obtain carbon templates, which were then infiltrated with metallic silicon to obtain silicon carbide with mimicked microstructures. The values found for moisture absorption, basic density and average mechanical strength in uniaxial compression were $6.51 \%, 0.49 \mathrm{~g} / \mathrm{cm}^{3}$ and 42.5 $\mathrm{MPa}$, respectively, for the tornillo and $6.99 \%, 0.42 \mathrm{~g} / \mathrm{cm}^{3}$ and $41.5 \mathrm{MPa}$, respectively, for the bolaina.

Samples of biomorphic SiC derived from tornillo and bolaina presented a homogeneous and porous microstructure, the phases of $\mathrm{SiC}, \mathrm{Si}$ and remaining carbon could be clearly identified. The mechanical results of the $\mathrm{SiC}$ samples studied showed high dispersion, with respect to the maximum resistance values, which ranged between 194 and $440 \mathrm{MPa}$ for the tornillo -derived SiC and between 30 and $77 \mathrm{MPa}$ for the bolaina -derived $\mathrm{SiC}$.
\end{abstract}

Keywords: silicon carbide, mechanical resistance, low-density wood, bolaina, tornillo, biomorphic

\section{Introduction}

Silicon Carbide is an advanced ceramic material widely used in industries such as high temperature processing, electronics, aerospace, abrasive treatment, engineering and armor (1-4); mainly due to its excellent properties of creep resistance, chemical stability, oxidation resistance, flexural strength and toughness at ambient and high temperatures.

Various investigations have focused on the manufacture and mechanical characterization of biomorphic $\mathrm{SiC}$ made from wood cellulose precursors. Currently one of the most promising methods for obtaining biomorphic carbide is the reactive infiltration of metallic silicon in a porous carbon preform due to its methodology being environmentally friendly, scalable and energy saving (5-6).

On the other hand, Peru is a country with a mega diverse flora that registers 4618 timber species, most of the low-density timber species have high strength, rigidity, tenacity, resistance to damage at micro and macro scales with a unique cellular structure, additionally It is a sustainable and renewable resource, which is why it becomes a promising resource for the production of biomorphic carbides, various investigations have focused on the use of low-density timber preforms because they can contain a large amount of Si during the infiltration processes of Si (7-13).

Therefore, the present study aims to take advantage of low-density Peruvian timber species for the manufacture of biomorphic carbides.

\section{Materials and Methods}

After conducting a brief diagnosis of the reality of the timber industry in Peru, it was determined that the tornillo and the bolaina are commercial, abundant and representative woods within the group of low-density Peruvian timber species. In this work, the selected woods were characterized by moisture absorption techniques, basic density that is used to calculate the dry mass of the wood that it has in volume in green (the Peruvian standard NTP 251.011 2014: Determination of density of wood, was used), optical microscopy (they were performed in an AMSCOPE brand optical microscope (50X - 500X), model ME320B-PZ, USA), and uniaxial compression (it was carried out in a universal testing machine brand MICROTEST, 
model EM1/50/FR, Spain). Both types of wood were subjected to thermal processes of (i) pyrolysis in an inert atmosphere $\left(900^{\circ} \mathrm{C}\right.$ and 0.5 hours of isotherm), following the thermal cycle of Fig. 1(a) and (ii) reactive infiltration with metallic silicon at temperatures of $1550{ }^{\circ} \mathrm{C}$ and in a vacuum atmosphere (Fig.1(b)). It should be noted that for all the $\mathrm{SiC}$ samples manufactured, $50 \%$ silicon was used in excess, with respect to the stoichiometric amount of the $\mathrm{SiC}$ molecule.
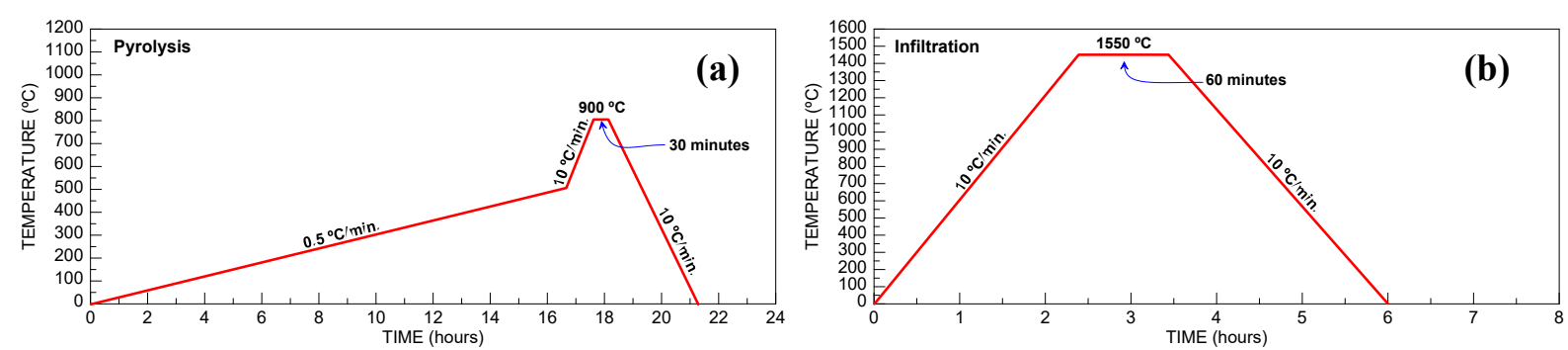

Fig. 1: Thermal profiles for the processes of (a) pyrolysis and (b) reactive infiltration.

The mechanical characterization of the $\mathrm{SiC}$ samples was carried out at a constant compression rate of 0.05 $\mathrm{mm} / \mathrm{min}$., in air atmosphere and at room temperature. The samples for the compression tests consisted of parallelepipeds of $3 \times 3 \times 6 \mathrm{~mm}^{3}$ and were obtained by cuts with a diamond edge disc, made on the largest samples of infiltrated SiC. Force and displacement data were obtained from the mechanical tests, which were then converted and analyzed into stress vs. deformation.

\section{Results and Discussion}

\subsection{Physical, Microstructural and Mechanical Characterization for Tornillo and Bolaina}

The average basic density for the precursor woods was 0.49 and $0.42 \mathrm{~g} / \mathrm{cm}^{3}$ for the tornillo and bolaina, respectively. Fig. 2 shows carbon optical microscopy micrographs of the two types of selected woods. Both surfaces observed are of the cross-section (with respect to the growth direction of the tree) and are clearly defined. The microstructure of the tornillo and bolaina samples consist of a single continuous phase, with the presence of evenly distributed pores in darker contrast. With the support of the digital image processor ImageJ, the diameters of the largest porosities of both samples were determined. Resulting in an average porosity diameter for the bolaina of $155.8 \mu \mathrm{m}$ and for tornillo of $221.6 \mu \mathrm{m}$.
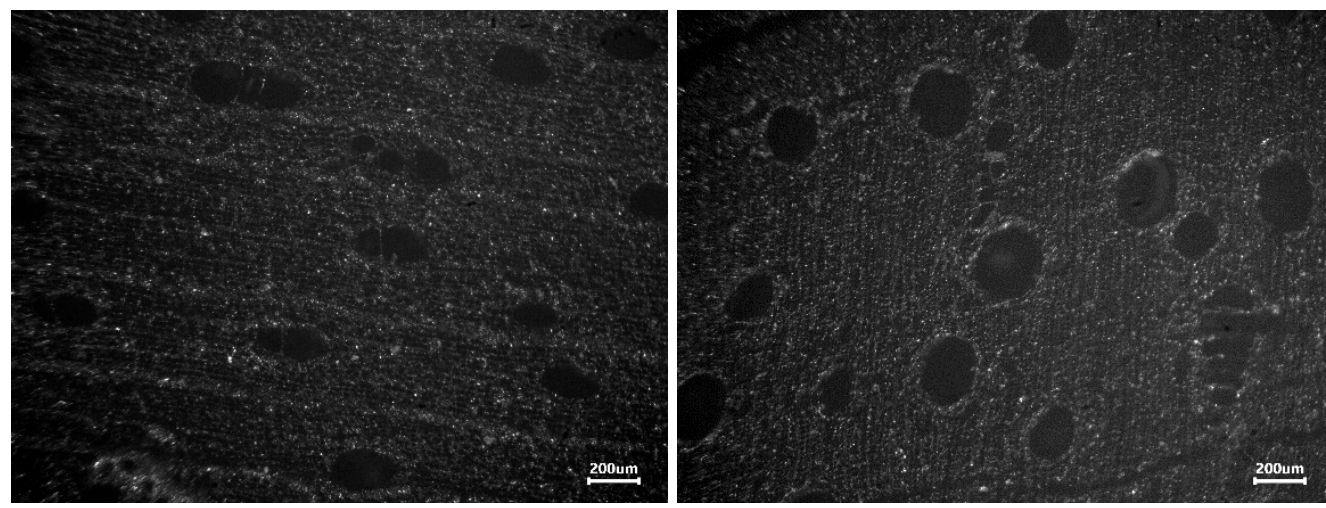

Fig. 2: Micrographs of the carbon cross section obtained by optical microscopy from samples

(a) bolaina and (b) tornillo

Fig. 3 shows stress vs. deformation for tornillo (Fig. 3(a)) and bolaina (Fig. 3(b)) samples in the direction parallel to the fibers. The mechanical results obtained from the precursor woods show similar mechanical strengths for both types of wood with maximum strength values of between 38 and $47 \mathrm{MPa}$ for the screw and between 35 and $48 \mathrm{MPa}$ for the bolaina. It is worth noting a slight greater rigidity in the bolaina, with respect to the tornillo, and greater deformations in the tornillo compared to the bolaina. 

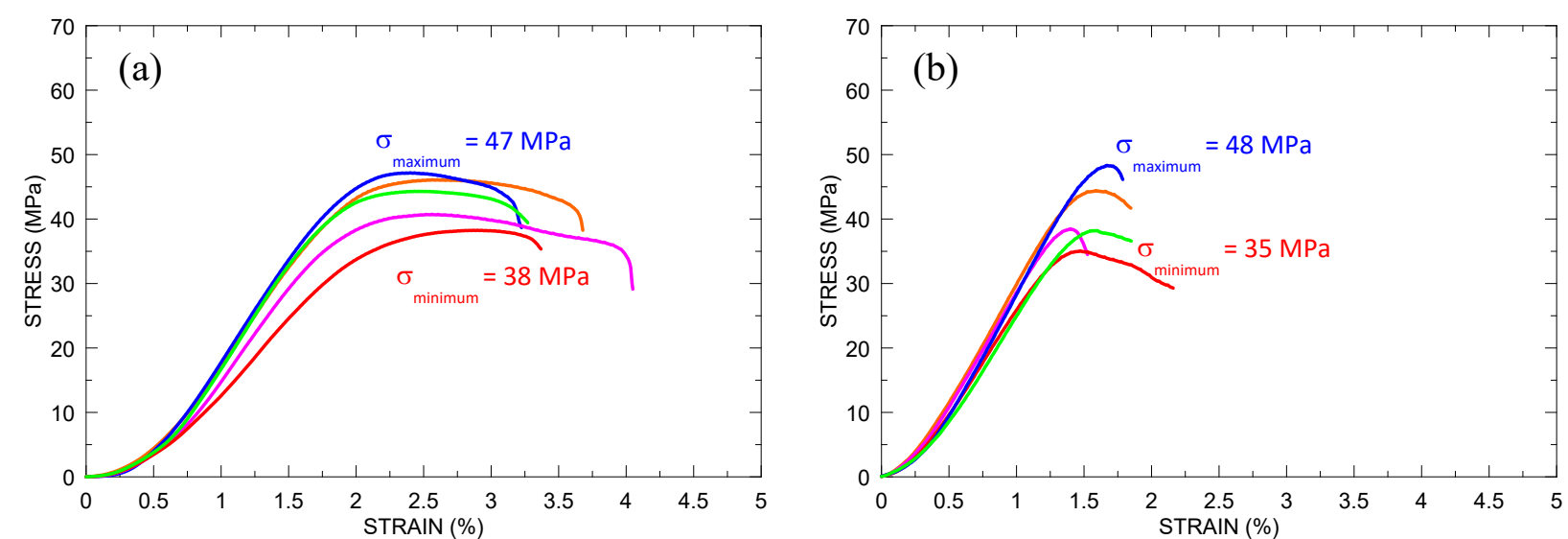

Fig. 3: Stress vs. strain for (a) tornillo wood and (b) bolaina wood tested at constant compression rate and at room temperature

\subsection{Mechanical Characterization Sic Derived From Tornillo and Bolaina}

Fig. 4 presents stress vs. strain curves for silicon carbide derived from tornillo wood (Fig. 4(a)) and bolaina wood (Fig. 4(b)). In both groupings of curves, the low repeatability of maximum resistance results could be evidenced, varying from 194 to $440 \mathrm{MPa}$ for the case of tornillo $\mathrm{SiC}$ and from 30 to $77 \mathrm{MPa}$ for bolaina SiC. This result suggests considering nonstructural applications for the manufactured materials, considering the use of tornillo $\mathrm{SiC}$ in applications that demand mechanical strengths less than $190 \mathrm{MPa}$ and applications with mechanical requirements less than $30 \mathrm{MPa}$ for $\mathrm{SiC}$ derived from bolaina. It was also possible to observe greater deformations in screw $\mathrm{SiC}$, with respect to bolaina $\mathrm{SiC}$.
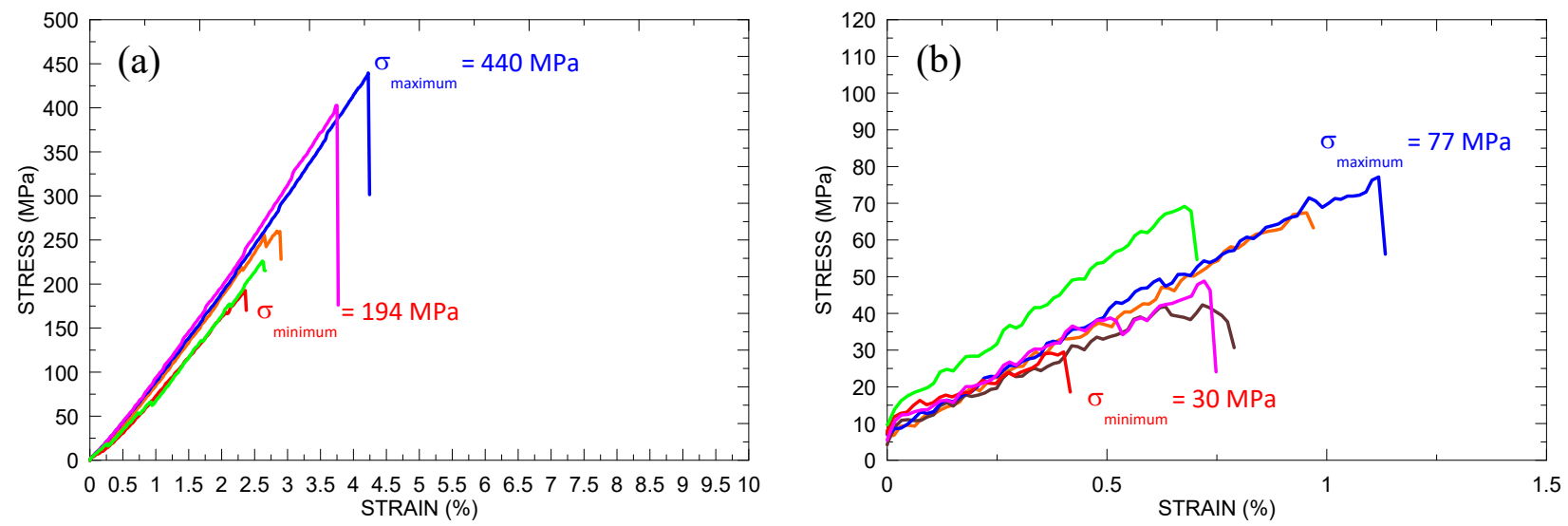

Fig. 4. Stress vs. strain for biomorphic SiC derived from (a) tornillo wood and (b) bolaina wood obtained in uniaxial compression and at room temperature

\section{Conclusions}

$\mathrm{SiC}$ materials have been successfully manufactured from low density wood precursors (tornillo and bolaina), following the procedures established in the literature on pyrolysis of wood in an inert atmosphere followed by reactive infiltration of metallic silicon in carbon preforms.

The basic density values found for the tornillo and bolaina were 0.49 and $0.42 \mathrm{~g} / \mathrm{cm}^{3}$, respectively, these being very close to each other. Both species of wood are considered low-density commercial woods.

The microstructures found in the wood samples revealed the presence of a single phase made up of short fibers and well distributed rounded porosities.

The average large porosity diameter of bolaina and tornillo were $155.8 \mu \mathrm{m}$ and $221.6 \mu \mathrm{m}$, respectively. This characteristic is key to the infiltration process in the preform, since the smaller the pore size, its obstruction by the formation of $\mathrm{SiC}$ is more feasible. 
The maximum mechanical strengths in uniaxial compression, obtained in the direction parallel to the fibers, showed very similar values for the tornillo and the bolaina, however, a larger plastic region could be observed in the tornillo, compared to what was observed in the bolaina.

It was not possible to show repeatability in the uniaxial compression tests performed on $\mathrm{SiC}$ samples derived from tornillo and bolaina, which suggests that the $\mathrm{SiC}$ materials studied in this work are intended for non-structural applications.

\section{Acknowledgements}

This work was financed by CONCYTEC - FONDECYT within the framework of call E041-01 with contract $\mathrm{N}^{\circ}$ 36-2018-FONDECYT-BM-IADT-AV and was executed in the laboratories of the Universidad Católica San Pablo.

\section{References}

[1] Li, F., Liu, J., Huang, X., Zhang, G., "Porous Ultra-High Temperature Ceramics: Preparation, Structure and Properties", J. of the Chin. Ceram. Soc., vol 46, no.12, pp. 1669-1684, 2018.

[2] Y. Katoh, L. Snead. "Silicon carbide and its composites for nuclear applications - historical overview", J. Nucl. Mater., vol 526, p. 151849, 2019

[3] P.G. Karandikar, G. Evans, S. Wong, M.K. Aghajanian, “A review of ceramics for armor applications”, L. Prokurat Franks (Ed.), Advances in Ceramic Armor IV, John Wiley \& Sons, pp. 163-175, 2009

[4] Nataliya D. Shcherban, "Review on synthesis, structure, physical and chemical properties and functional characteristics of porous silicon carbide", J. of Ind. and Eng. Chem., vol. 50, pp. 15-28, 2017.

[5] M.A. Bautista, J. Quispe Cancapa, J. Martinez Fernandez, M.A. Rodríguez, M. Singh, "Microstructural and mechanical evaluation of porous biomorphic silicon carbide for high temperature filtering applications", J. of the Eur. Ceram. Soc., pp. 1325-1332, 2011.

[6] P.S. Grinchuk, M.V. Kiyashko, H.M. Abuhimd, M.S. Alshahrani, D.V. Solovei, M.O. Stepkin, A.V. Akulich, M.D. Shashkov, T.A. Kuznetsova, S.M. Danilova-Tretiak, L.E. Evseeva, K.V. Nikolaeva, "Advanced technology for fabrication of reaction-bonded SiC with controlled composition and properties", J. of the Eur. Ceram. Soc., 2021,

[7] Min Yu, Guo-jun Zhang, Theo Saunders, "Wood-derived ultra-high temperature carbides and their composites: A review", Ceram. Inter., vol. 46, no. 5, pp. 5536-5547, 2020

[8] Parlett, C.M.A., Wilson, K., Lee, A.F., "Hierarchical porous materials: Catalytic applications", Chem. Soc. Rev., vol. 42, no. 9, pp. 3876-3893, 2013.

[9] J.F. Gamarra-Delgado, J.J. Paredes-Paz, V.C. Bringas-Rodríguez, D.L. Mayta-Ponce, G.P. Rodríguez-Guillén, F.A. Huamán-Mamani, "Mechanical and Thermomechanical Behavior of Sic/Si Compounds Subjected to Controlled Atmospheric Conditions", Int. J. of Min., Mater., and Metal. Eng., pp. 53-59, 2020.

[10] C. Ulloa Ulloa, P. Acevedo- Rodriguez, S. Beck, M.J. Belgrano, R. Bernal, P.E. Berry, L. Brako, M. Celis, G. Davidse, R.C. Forzza, S.R. Gradstein, O. Hokche, B. León, S. León-Yánez, R.E. Magill, D.A. Neill, M. Nee, P.H. Raven, H. Stimmel, M.T. Strong, J.L. Villaseñor, J.L. Zarucchi, F.O. Zuloaga, P.M. Jørgensen, “An integrated assessment of the vascular plant species of the Americas" Science., vol 358, no. 6370, pp. 1614-1617, 2017

[11] R. Vásquez, R. Rojas, A. Monteagudo, L. Valenzuela, I. Huamantupa, "Catálogo de los árboles de Perú" in Rev. Q'euña. Perú, 2018.

[12] José Luis Marcelo-Peña, Fidel A. Roig, Zoë A. Goodwin, Mario Tomazello-Filho, "Characterizing growth rings in the trees of Perú: A wood anatomical overview for potential applications in dendroecological-related fields", Dendroch., vol. 62, p.125728, 2020.

[13] D. Lee, J. Jang, H. Park, Y. Kim, K. Lim, S. Park, S. Hong, "Fabrication of biomorphic SiC composites using wood preforms with different structures" Ceram. Int., vol. 38, no. 4, pp. 3089-3095, 2012. 